\title{
A DATA ENVELOPMENT ANALYSIS APPROACH FOR MEASURING THE EFFICIENCY OF EMPLOYEES: A CASE STUDY
}

\author{
Hadi Shirouyehzad $^{1 *}$, F. Hosseinzadeh Lotfi ${ }^{2}$, Mir. B. Aryanezhad ${ }^{3} \&$ Reza Dabestani ${ }^{4}$ \\ ${ }^{1}$ Department of Industrial Engineering, Science and Research Branch \\ Islamic Azad University, Tehran, Iran \\ hadi.shirouyehzad@gmail.com \\ ${ }^{2}$ Department of Mathematics, Science and Research Branch \\ Islamic Azad University, Tehran, Iran \\ ${ }^{3}$ Department of Industrial Engineering \\ Iran University of Science \& Technology, Tehran, Iran \\ ${ }^{4}$ Department of Management \\ Isfahan University, Isfahan, Iran
}

\begin{abstract}
Human resource management has become ever more important to organisational success. Many organisations have therefore realised that human resource management and performance can provide competitive advantage. The purpose of this study is to introduce a practical model for assessing employees' efficiency. In this paper, a model related to the data envelopment analysis (DEA) approach is developed to calculate such efficiency. Physical working conditions, salary, responsibilities allocated, and the amount of work to be done are considered the main factors that may influence employees' efficiency. The Andersen-Petersen model and a brief statistical analysis are used to rank employees and to analyse their efficiency value, based on demographic characteristics. The study confirms that physical working conditions and organisational commitment are the main factors that affect employees' efficiency.
\end{abstract}

\section{OPSOMMING}

Menslike-hulpbronbestuur speel 'n al belangriker rol in die sukses van ' $n$ onderneming. Gevolglik het talle ondernemings besef dat menslike-hulpbronbestuur en werkverrigting ' $n$ mededingende voordeel kan bied. Die doel van hierdie studie is om ' $n$ praktiese model vir die assessering van werknemers se doeltreffendheid bekend te stel. 'n Model, wat verband hou met die 'data envelopment analysis (DEA)'-benadering, is ontwikkel om die doeltreffendheid te bereken. Fisiese werkomstandighede, salaris, verantwoordelikhede toegewys en die werklading word beskou as die belangrikste faktore wat werknemer-doeltreffendheid kan beïnvloed. Die Anderson-Petersen-model en 'n bondige statistiese analise is gebruik om werknemers te rangskik om sodoende hul doeltreffendheidswaarde te analiseer, gebaseer op demografiese kenmerke. Die studie bevestig dat fisiese werks-omstandighede en die verbintenis van die organisasie die belangrikste faktore is wat werknemers doeltreffendheid beïnvloed.

\footnotetext{
* Corresponding author
} 


\section{INTRODUCTION}

As a subject for management's attention, performance is not only limited to concepts like productivity, efficiency or effectiveness. It has been considered by social scholars from a variety of perspectives. More recently, research has been done into the relationship between the concept of human resource management and organisational performance [1]. Analysing the impact of human resource management on performance has become one of the challenges facing managers'. Performance is typically assessed based on a rating scale that allows the respondent to estimate the importance of performance factors. Statistically, methods such as correlation, regression, or structural equation models can be applied to achieve this purpose $[2,3,4]$.

There are a vast number of concepts that may influence a company's performance. The main factors that can be related to HRM are job satisfaction, organisational commitment, motivation, and turnover. So organisations can improve their performance through increasing employee satisfaction, organisational commitment [5], and motivation, and by reducing turnover [6]. According to traditional approaches, an employee with a high performance is better than others. Based on the DEA approach, an employee with the highest performance is not necessarily the most efficient. DEA has been used in economic analysis for recognising technically efficient operations [7]. It is a linear programming method that integrates partial efficiency measures into a single unit, and provides objective evaluation and consistent comparisons of technical efficiency among decisionmaking units (DMUs).

In this paper the, each employee is regarded as a decision-making unit (DMU). Each DMU has inputs and outputs. In this model, the inputs are salary, physical working conditions, level of responsibility, and amount of work. The outputs of the DEA model are the factors that influence performance: job satisfaction, organisational commitment, motivation, and turnover. Data for these parameters are gathered through questionnaires in a pipe industry. A ranking model and brief statistical analysis are also used to analyse the employees' efficiency numbers, based on the demographic characteristics. The findings show that physical working conditions and organisational commitment are the main factors that influence employees' efficiency.

\section{CONCEPTUAL BACKGROUNDS}

\subsection{Organisational commitment}

Organisational commitment can be described as a multi-dimensional work attitude that concerns the relationship between employees and their organisation [8]. Classically, it is the acceptance of organisational goals, a willingness to make an effort, and a desire to stay in the organisation [9]. Organisational commitment is closely related to positive feelings for an organisation. In essence, measuring organisational commitment is an assessment of the congruence between employees' values and their beliefs in the objectives of the organisation [10]. It is also proved that organisational commitment correlates highly with valuable organisational commitment, including job performance ratings, low intent to search for a new job, and lower turnover [11]. By understanding commitment, HRM practitioners will be in a better position to anticipate the impact of a particular policy or practice on the organisation [11,12]. High levels of organisational commitment provide a clear focus for human resource managers on the grounds that commitment is in itself a good and positive thing that should lead to high levels of work performance [9].

\subsection{Job satisfaction}

Job satisfaction can be defined as a positive emotional state resulting from the pleasure that a worker takes from doing the job [13], and as the affective and cognitive attitudes held by an employee towards different dimensions of his/her work [14]. It is the extent to which one feels positively or negatively about the intrinsic and/or extrinsic aspects of one's job [15]. Job satisfaction has also been an interesting subject for researchers seeking to 
understand employees' behaviours and attitudes [12]. Job satisfaction is directly related to organisational commitment [16], and is also directly [7] or indirectly [16] related to turnover intentions [12]. To measure 'job satisfaction' accurately, a number of criteria related to the job should be evaluated in order to consider a broad range of employee beliefs and attitudes towards the job.

\subsection{Turnover}

Employee turnover is one of the most important issues in organisational analyses. Despite wide progress in research on this topic, there is still much confusion about the factors that cause employees to leave or remain in their organisations. Major factors may include external ones (the labour market); institutional factors (such as physical working conditions, payment, job skill, supervision, and so on); an employee's personal characteristics (such as intelligence, aptitude, personal history, gender, interests, age, and length of service) and an employee's reaction to his/her job (including job satisfaction, job involvement, and job expectations). Both absenteeism and turnover are very costly to the organisation. These two factors may lead to lower productivity and profitability, and higher costs in hiring, retention, and training [18].

\subsection{Motivation}

The importance of discovering, comprehending, and considering employee motivation has been a principal concern for organisations, managers, and even first-line supervisors, because employee motivation influences the work performance of employees. The vital role of employee motivation, and of influencing the employee's attitudes to his/her behaviour, can ultimately lead to an organisation's success or failure [19].

\subsection{Data envelopment analysis}

Efficiency measurement has been an important issue for organisations that have struggled to improve their own productivity and efficiency. Reasons for this were fully set out 50 years ago in Farrell's classic paper [20] on the measurement of productive efficiency. Farrell also affirmed that the main reason for failure in solving problem was the unjustified combination of multiple inputs into any satisfactory measure of efficiency. Charnes et al. [21] also stated the need for satisfactory procedures to evaluate the relative efficiencies, based on the multiple inputs and outputs that have been called 'data envelopment analysis' (DEA).

\section{METHODOLOGY}

Researchers have tried to prove the vital casual link between suitable human resource policies and organisational performance. They state that firms should use appropriate human resource policies to increase their organisational performance. Among these factors, job satisfaction, organisational commitment, motivation, and turnover have been regarded as the most important and most effective human resource dimensions of organisational performance. Therefore these factors can be used to analyse organisational performance.

\subsection{Motivation}

In this paper, a job characteristic model is used to measure employees' motivation. The Hackman \& Oldham job characteristics model is the dominant one for studying the impact of job characteristics on affective work outcomes (such as job satisfaction, empowerment, and motivation) and to a more limited extent the behavioural outcomes (such as performance, absenteeism, and turnover intentions). The Job Characteristics Scales (JCS) are a component of the Job Diagnostic Survey (JDS), the most widely-used instrument across many types of jobs to measure perceived job characteristics. Hackman \& Oldham [22], in a study of work redesign, noted that "problems stemming from unsatisfactory relationships between people and their jobs can be remedied by restructuring the jobs that are performed, rather than by continuing efforts to select, train, direct, and motivate people so that they fit better with the requirements of fixed jobs". Hackman \& Oldham [23] have also identified and defined the five job characteristics: skill variety (SV), task 
identity (TI), task significance (TS), autonomy (AU), and feedback (FB). They maintain that job satisfaction, motivation, work quality, and performance are influenced by these five core job dimensions. They developed the Job Diagnostic Survey (JDS) to measure the variables and produce a Motivating Potential Score (MPS). The MPS is derived from the following formula:

$$
M P S=\frac{S V+T I+T S}{3} \times A U \times F B
$$

\subsection{Job satisfaction}

To assess the attitude of employees to certain aspects of their job, Spector [24] developed a job satisfaction measurement technique using 36 items and nine subscale measures. The nine subscales are pay, promotion, supervision, fringe benefits, contingent rewards (performance-based rewards), operating procedures (required rules and procedures), coworkers, nature of work, and communication. Each subscale includes four items. The total score is computed from all items. While job satisfaction was originally developed for use in human service organisations, Spector stated that it could be used for other departments as well. The response format is a five-point Likert scale, ranging from 'disagree very much' (1) to 'agree very much' (5).

\subsection{Organisational commitment}

Mowbray et al. [25], authors of a widely-studied publication that measures affective attachment to the organisation, The Organisational Commitment, state that organisational commitment is frequently found in the strength of an individual's identification with and involvement in a particular organisation. It includes the extent to which the individual (1) accepts and believes in the organisation's goals; (2) is willing to exert effort on behalf of the organisation; and (3) wants to continue involvement in the organisation. The first two components represent attitudinal commitment, while the third one is behavioural [26].

\subsection{Turnover}

Turnover is one of the main factors affecting an employee's performance. Thus an employee's wish to abandon the company can be measured through a questionnaire. In this study, five questions are put to employees to examine their wish to leave the company.

\section{DEA MODELLING}

Data envelopment analysis (DEA) is a mathematical programming methodology. DEA was initially developed as one way to assess the comparative efficiencies of organisational units. It has been used successfully to assess the relative performance of a set of firms, usually called decision-making units (DMU), which use the same inputs to produce the same outputs.

Assume that there are $\mathrm{N}$ DMUs that convert I inputs to $\mathrm{J}$ outputs. In particular, let the $\mathrm{m}_{\text {th }}$ DMU produce outputs $y_{j m}$ using $x_{i m}$ inputs. The objective of the DEA approach is to identify the DMUs that produce the greatest number of outputs by consuming the lowest number of inputs. A DMU is deemed to be efficient if the ratio of the weighted sum of outputs to the weighted sum of inputs is the highest. Input and output variables of the DEA model are shown in Figure 1. In this paper, an employee is considered to be a DMU. The DMU inputs are salary, physical working conditions, irresponsibility, and amount of work. The outputs are motivation, job satisfaction, organisational commitment, and turnover. The outputs and inputs are explained in Table 1. The DMU defined in this study, with input and output criteria, is as SHOWN IN Figure 1. 


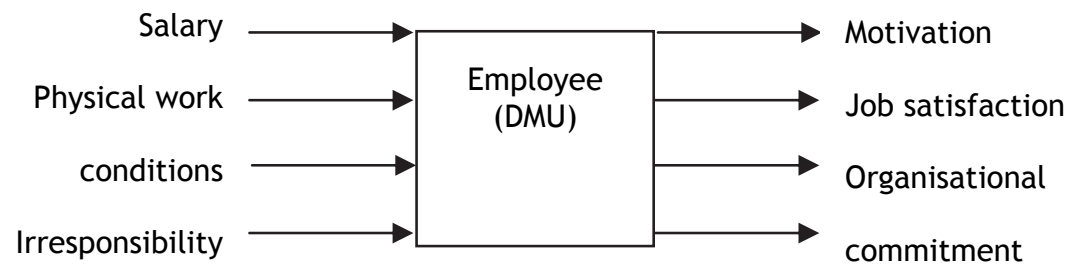

Figure 1: DEA model

The format of the DEA model used in this study is based on multiple inputs and outputs. The following is a generalised formulation of the DEA model to measure employees' efficiency.

Outputs are the main factors that influence employees' performance, and can be measured through questionnaires. But this kind of measurement is rigid because it does not consider the inputs values that may influence outputs. For example, employees who receive higher salaries or have better working conditions may have a higher motivation and job satisfaction. The values of the outputs that are measured by questionnaires include motivation, job satisfaction, organisational commitment, and turnover. Increasing the motivation, job satisfaction, and organisation commitment - and decreasing turnover should be the aim of each company. Since the DEA method tries to increase the outputs and decrease the inputs, turnover is assumed to be an input, because the nature of this variable is negative.

Minimize $\theta_{0}-\varepsilon\left(\sum_{i=1}^{m} S_{i}^{-}+\sum_{i=1}^{m} S_{r}^{+}\right)$

where

$\theta_{\mathrm{o}} x_{i o}-\sum_{j=1}^{n} x_{i j} \lambda_{j}-s_{i}^{-}=0$ for all $\mathrm{i}=1, \ldots, \mathrm{m}$

$\mathrm{y}_{\text {ro }}-\sum_{j=1}^{n} y_{r j} \lambda_{j}+s_{r}^{+}=0 \quad$ for all $\quad \mathrm{r}=1, \ldots, \mathrm{s}$

$\lambda_{j}, s_{i}^{-}, \mathrm{s}_{\mathrm{r}}^{+} \geq 0 \quad$ for all $\mathrm{j}=1, \ldots, \mathrm{n} \quad \mathrm{i}=1, \ldots, \mathrm{m} \quad \mathrm{r}=1, \ldots, \mathrm{s}$

$\theta_{\mathrm{o}}$ Unconstrained but assumed positive

Where:

$\theta_{\mathrm{o}}$ is the efficiency measure for employee o;

$\lambda_{j}$ are reference weights associated with employee $\mathrm{j}$;

$s_{i}^{-}$are input criteria slack variables;

$S_{r}^{+}$are output criteria surplus variables;

$\varepsilon$ is an infinitesimally small number;

$\mathrm{m}$ is the number of input criteria;

$\mathrm{n}$ is the number of employees;

$s$ is the number of output criteria.

$x_{i j}$ is the input criteria value for the $i_{t h}$ criteria and the $j_{\text {th }}$ employee;

$y_{r j}$ is the output criteria value for the $r_{\text {th }}$ criteria and the $j_{t h}$ employee; 


\begin{tabular}{|l|l|}
\hline Inputs & Outputs \\
\hline $\begin{array}{l}\text { 1. Salary: employees received monetary raise } \\
\text { or bonus, or did not receive desired raise or } \\
\text { bonus }\end{array}$ & 1. Motivation: desire to work in the company \\
\hline $\begin{array}{l}\text { 2. Physical working condition: temperature, } \\
\text { machinery, hours of work were pleasant and } \\
\text { manageable, or they were unpleasant }\end{array}$ & $\begin{array}{l}\text { 2. Job satisfaction: a positive emotional state } \\
\text { resulting from the pleasure a worker derives from the } \\
\text { job }\end{array}$ \\
\hline $\begin{array}{l}\text { 3. Irresponsibility: Does the employee not } \\
\text { wish to be given special assignments? }\end{array}$ & $\begin{array}{l}\text { 3. Organisational commitment: individual's belief in } \\
\text { and acceptance of the goals and values of the } \\
\text { organisation, and a strong desire to remain in the } \\
\text { organisation }\end{array}$ \\
\hline $\begin{array}{l}\text { 4. Amount of work: related to the total tasks } \\
\text { for which an employee is responsible in } \\
\text { his/her position }\end{array}$ & $\begin{array}{l}\text { 4. Turnover: the rate at which employees leave a } \\
\text { workforce }\end{array}$ \\
\hline
\end{tabular}

Table 1: Inputs and outputs in DEA model

\section{CASE STUDY}

\subsection{Sample and data collection}

The sample in this study is employees working in a pipe company. Four questionnaires were given to 55 employees, and their design was based on the stated methodology using a fivepoint Likert scale ( 1 as very low, 2 as low, 3 as moderate, 4 as high, and 5 as very high). In the questionnaires, 21 questions related to motivation, 36 questions to job satisfaction, 16 to organisational commitment, and five to turnover. Before distributing the final questionnaires, they were checked by several human resource executives to ensure that they were understandable and met the requirements.

All the employees worked in the central office of Darakar Co. and Plasticfar Co. in the Isfahan Province of Iran. Employees there are classified as administrative staff (responsible for carrying out office management activities), technical staff (responsible for the technical activities of the organisation), and production line staff. The number of input variables for each employee was also gathered through analysis of the nature of the employees' job and their personal information.

\subsection{Demographic characteristics}

Table 2 addresses the demographic characteristics of the employees. The majority of the respondents were young people: 55 percent were between 25 and 35 years old, while 16.5 percent were between 18 and 25 years old; another 16.5 percent were between 35 and 45 years old. Furthermore, 40 percent of the employees had between one and five years' tenure in their present jobs, and four percent of them had held their jobs for more than 20 years. Based on the manager status category, 78 percent of the respondents were nonsupervisory, while the rest were supervisors. The majority of the employees had a diplomalevel education (54.5 percent), while 14.5 percent had Bachelor's degrees. A statistical analysis was undertaken of the data acquired. 


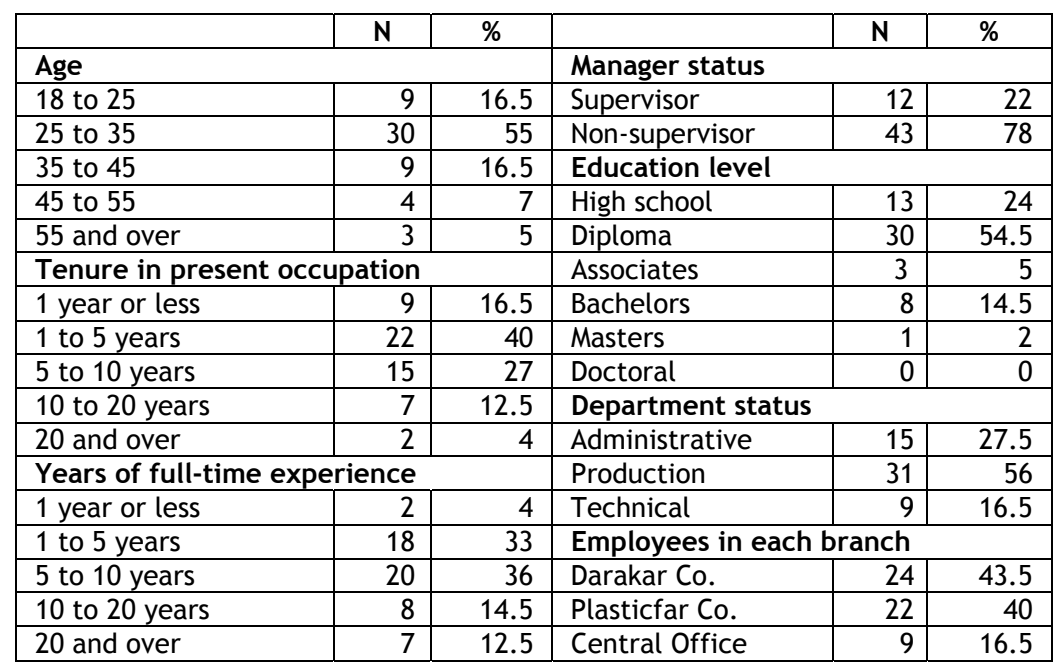

Table 2: Sample demographic characteristics

\section{RESULTS}

Employees' efficiency is measured through the CCR model represented in the DEA modelling section. Data on the inputs and outputs are derived from the questionnaires and the analysis of the employees' job nature and their personal information. The results of the DEA model for 55 employees are shown in Table 3. It will be noted that 10 employees have the highest efficiency of all the employees in the sample. These efficient employees work in the administrative, production, and technical departments. The lowest efficiency is found in employees 14 and 22, who work in the administrative department. Employees who earn a high salary in comparison with others do not necessarily have higher job satisfaction. For example, the salary of DMU 22 is higher than the other employees, but he does not have high job satisfaction, motivation, or organisational commitment. The efficiency of this employee is about 0.5 , which is relatively lower than the others. Cronbach's alpha of the data is calculated, and denotes a reliability level of 0.853 , which is satisfactory.

\begin{tabular}{|c|c|c|c|c|c|c|c|}
\hline DMU & Efficiency & DMU & Efficiency & DMU & Efficiency & DMU & Efficiency \\
\hline $\mathbf{1}$ & 0.9925 & $\mathbf{1 5}$ & 1.0000 & $\mathbf{2 9}$ & 0.8642 & $\mathbf{4 3}$ & 0.7344 \\
\hline $\mathbf{2}$ & 0.8883 & $\mathbf{1 6}$ & 0.9286 & $\mathbf{3 0}$ & 0.9387 & $\mathbf{4 4}$ & 0.9001 \\
\hline $\mathbf{3}$ & 0.9650 & $\mathbf{1 7}$ & 0.8589 & $\mathbf{3 1}$ & 1.0000 & $\mathbf{4 5}$ & 0.9158 \\
\hline $\mathbf{4}$ & 1.0000 & $\mathbf{1 8}$ & 0.8996 & $\mathbf{3 2}$ & 0.9436 & $\mathbf{4 6}$ & 0.8758 \\
\hline $\mathbf{5}$ & 0.9402 & $\mathbf{1 9}$ & 0.8918 & $\mathbf{3 3}$ & 0.9103 & $\mathbf{4 7}$ & 0.9709 \\
\hline $\mathbf{6}$ & 1.0000 & $\mathbf{2 0}$ & 1.0000 & $\mathbf{3 4}$ & 1.0000 & $\mathbf{4 8}$ & 0.9389 \\
\hline $\mathbf{7}$ & 0.8784 & $\mathbf{2 1}$ & 0.8968 & $\mathbf{3 5}$ & 0.9051 & $\mathbf{4 9}$ & 1.0000 \\
\hline $\mathbf{8}$ & 0.9728 & $\mathbf{2 2}$ & 0.5346 & $\mathbf{3 6}$ & 0.9358 & $\mathbf{5 0}$ & 0.9516 \\
\hline $\mathbf{9}$ & 1.0000 & $\mathbf{2 3}$ & 0.7312 & $\mathbf{3 7}$ & 0.8933 & $\mathbf{5 1}$ & 0.8377 \\
\hline $\mathbf{1 0}$ & 0.9800 & $\mathbf{2 4}$ & 0.8351 & $\mathbf{3 8}$ & 0.7548 & $\mathbf{5 2}$ & 0.9127 \\
\hline $\mathbf{1 1}$ & 0.9900 & $\mathbf{2 5}$ & 0.9888 & $\mathbf{3 9}$ & 0.9058 & $\mathbf{5 3}$ & 0.7633 \\
\hline $\mathbf{1 2}$ & 1.0000 & $\mathbf{2 6}$ & 0.6764 & $\mathbf{4 0}$ & 0.8740 & $\mathbf{5 4}$ & 0.9543 \\
\hline $\mathbf{1 3}$ & 0.8914 & $\mathbf{2 7}$ & 0.8877 & $\mathbf{4 1}$ & 0.9447 & $\mathbf{5 5}$ & 0.8185 \\
\hline $\mathbf{1 4}$ & 0.6322 & $\mathbf{2 8}$ & 0.6838 & $\mathbf{4 2}$ & 1.0000 & & \\
\hline
\end{tabular}

Table 3. Results of DEA modelling

Table 4 gives more detail of employees' efficiency in each category. The largest group of efficient employees are those aged 25-35, with 1-5 years of tenure in their present occupation, and 5-10 years of full experience. Most of them work in the production department. The majority of these employees have a diploma or degree in their education. The highest efficiency average is related to the 18-25 and 25-35 age categories. The findings show that older employees have a lower efficiency. There is also a negative 
relationship between employees' tenure, experience, education level, and efficiency. Based on the results of this study, less experienced employees have a higher efficiency than experienced employees. In term of education level, employees with a diploma or less have a higher efficiency than others.

\begin{tabular}{|c|c|c|c|c|c|c|}
\hline Category & $\mathrm{N}$ & $\begin{array}{l}\text { No. efficient } \\
\text { employees }\end{array}$ & Average & Variation & Max & Min \\
\hline \multicolumn{7}{|l|}{ Age } \\
\hline 18 to 25 & 9 & 1 & 0.9398 & 0.0016 & 1 & 0.8883 \\
\hline 25 to 35 & 30 & 7 & 0.9227 & 0.0085 & 1 & 0.5346 \\
\hline 35 to 45 & 9 & 2 & 0.8694 & 0.0172 & 1 & 0.6322 \\
\hline 45 to 55 & 4 & 0 & 0.8134 & 0.0058 & 0.8918 & 0.7344 \\
\hline 55 and over & 3 & 0 & 0.7233 & 0.0013 & 0.7548 & 0.6838 \\
\hline \multicolumn{7}{|c|}{ Tenure in present occupation } \\
\hline 1 year or less & 9 & 3 & 0.9391 & 0.0025 & 1 & 0.8883 \\
\hline 1 to 5 years & 22 & 5 & 0.9240 & 0.0100 & 1 & 0.5346 \\
\hline 5 to 10 years & 15 & 2 & 0.9024 & 0.0064 & 1 & 0.7548 \\
\hline 10 to 20 years & 7 & 0 & 0.8078 & 0.0159 & 0.9387 & 0.6322 \\
\hline 20 and over & 2 & 0 & 0.7091 & 0.0013 & 0.7344 & 0.6838 \\
\hline \multicolumn{7}{|c|}{ Years of full-time experience } \\
\hline 1 year or less & 2 & 1 & 0.9718 & 0.0016 & 1 & 0.9436 \\
\hline 1 to 5 years & 18 & 2 & 0.9221 & 0.0025 & 1 & 0.8185 \\
\hline 5 to 10 years & 20 & 5 & 0.9265 & 0.0110 & 1 & 0.5346 \\
\hline 10 to 20 years & 8 & 1 & 0.8282 & 0.0180 & 1 & 0.6322 \\
\hline 20 and over & 7 & 1 & 0.8132 & 0.0120 & 1 & 0.6838 \\
\hline \multicolumn{7}{|l|}{ Manager status } \\
\hline Supervisor & 12 & 2 & 0.8300 & 0.0220 & 1 & 0.5346 \\
\hline Non-supervisor & 43 & 8 & 0.9169 & 0.0064 & 1 & 0.6764 \\
\hline \multicolumn{7}{|l|}{ Education level } \\
\hline High school or other & 13 & 4 & 0.9375 & 0.0050 & 1 & 0.7633 \\
\hline Diploma & 30 & 6 & 0.9157 & 0.0060 & 1 & 0.6838 \\
\hline Associates & 3 & 0 & 0.8287 & 0.0063 & 0.9127 & 0.7548 \\
\hline Bachelors & 8 & 0 & 0.7939 & 0.0030 & 0.9888 & 0.5346 \\
\hline Masters & 1 & 0 & 0.8933 & 0.0000 & 0.8933 & 0.8933 \\
\hline \multicolumn{7}{|l|}{ Department status } \\
\hline Administrative & 15 & 1 & 0.8377 & 0.0183 & 1 & 0.5346 \\
\hline Production & 31 & 8 & 0.9396 & 0.0033 & 1 & 0.7633 \\
\hline Technical & 9 & 1 & 0.8550 & 0.0125 & 1 & 0.6322 \\
\hline Total & 55 & 10 & 0.898 & 0.0107 & 1 & 0.5346 \\
\hline
\end{tabular}

Table 4: Statistical analysis for the employees' efficiency based on the demographic characteristics

\subsection{Ranking}

In order to rank efficient DMUs, the Andersen-Petersen model is used. The ranking model in this study is as follows: [27]

Minimize $\theta_{o}^{\prime}-\varepsilon\left(\sum_{i=1}^{m} S_{i}^{-}+\sum_{i=1}^{m} S_{r}^{+}\right)$

where

$\theta_{o}^{\prime} x_{i o}-\sum_{\substack{j=1 \\ j \neq 0}}^{n} x_{i j} \lambda_{j}-s_{i}^{-}=0$ for all $\mathrm{i}=1, \ldots, \mathrm{m}$

$\mathrm{y}_{\mathrm{ro}}-\sum_{\substack{j=1 \\ j \neq o}}^{n} y_{r j} \lambda_{j}+s_{r}^{+}=0 \quad$ for all $\mathrm{r}=1, \ldots, \mathrm{s}$

$\lambda_{j}, s_{i}^{-}, \mathrm{s}_{\mathrm{r}}^{+} \geq 0 \quad$ for all $\mathrm{j}=1, \ldots, \mathrm{n} \quad \mathrm{i}=1, \ldots, \mathrm{m} \quad \mathrm{r}=1, \ldots, \mathrm{s}$ 
$\theta_{o}^{\prime}$ Unconstrained but assumed positive

Where:

$\theta_{o}^{\prime}$ is the efficiency measure for employee o;

$\lambda_{j}$ are reference weights associated with employee $\mathrm{j}$;

$S_{i}^{-}$are input criteria slack variables;

$S_{r}^{+}$are output criteria surplus variables;

$\varepsilon$ is an infinitesimally small number;

$\mathrm{m}$ is the number of input criteria;

$\mathrm{n}$ is the number of employees;

$s$ is the number of output criteria.

$x_{i j}$ is the input criteria value for the $i_{\text {th }}$ criteria and the $j_{\text {th }}$ employee;

$y_{r j}$ is the output criteria value for the $r_{t h}$ criteria and the $j_{t h}$ employee;

Since 10 DMUs are efficient in this study, these DMUs are ranked through the abovementioned model. The ranking results are shown in Table 5. These DMUs do not necessarily have better inputs and outputs criteria than the others. The main factor among efficient DMUs is physical working conditions. The highest rank in Table 5 refers to employee 15, who worked in the production department.

\begin{tabular}{|l|c|l|l|l|l|}
\hline DMU & $\theta^{\prime}$ & Rank & DMU & $\theta^{\prime}$ & Rank \\
\hline $\mathbf{4}$ & 1.1107 & 5 & 20 & 1.2000 & 3 \\
\hline $\mathbf{6}$ & 1.3407 & 2 & $\mathbf{3 1}$ & 1.0239 & 8 \\
\hline $\mathbf{9}$ & 1.0158 & 9 & $\mathbf{3 4}$ & 1.0285 & 7 \\
\hline $\mathbf{1 2}$ & 1.1255 & 4 & $\mathbf{4 2}$ & 1.0285 & 6 \\
\hline $\mathbf{1 5}$ & 1.3975 & 1 & $\mathbf{4 9}$ & 1.0063 & 10 \\
\hline
\end{tabular}

Table 5: Ranking results

\section{DISCUSSION AND CONCLUSIONS}

The overall objective of this study was to evaluate the efficiency of employees through the DEA approach. In recent years there have been a great variety of applications of DEA in evaluating the performance of many different kinds of entities in different activities and contexts. One reason is that DEA has opened up possibilities in cases that have been resistant to other approaches because of the complex nature of the relations between the multiple inputs and multiple outputs involved in many activities. Other problems and limitations are also found in traditional attempts to evaluate efficiency when multiple outputs and multiple inputs need to be taken into account. Another advantage of this approach is that it natural, and easily makes contact with linear programming methods and concepts. The relatively new approach embodied in DEA does not require the user to prescribe the weights to be attached to each input and output, as well as the usual index/number approaches.

In this paper the employees' efficiency was calculated through the DEA approach. Each employee was considered as a DMU. Salary, physical working conditions, and irresponsibility were considered as input criteria, and performance as an output criterion. In order to determine the employees' performance, various factors were considered: motivation, organisational commitment, job satisfaction, and turnover. The turnover element is not a positive one, and so was seen as an input in the DEA model. The model was implemented in Darakar Co. and Plasticfar Co. to calculate the efficiency of 55 employees. The study revealed that the most efficient employees have a relatively high organisational commitment and suitable physical working conditions. In contrast, there was no significant relationship between irresponsibility, amount of work, and salary as the inputs of the DEA model and its efficiency value. This indicated that salary is not the main factor to affect 
employees' efficiency. Employees earning higher salaries do not necessarily have higher job satisfaction. The results obtained here do not differ from the findings of previous studies in the past decade, in which a positive relationship between high commitment and organisational performance is reported $[28,29,30,31]$.

However, the findings indicate the importance of physical working conditions and organisational commitment, it is recommended that companies focus on the ergonomic aspects of the organisation. Increasing salaries may not necessarily lead to higher job satisfaction and better performance. Companies should also find ways to increase organisational commitment. Statistical analysis also proves that older, more experienced and better educated employees do not have a high efficiency than others. This finding can be discussed in further research in order to find the causes. It is recommended that further study be undertaken to implement this model by dividing employees into subgroups such as age, education level, tenure, management status, etc. Sensitivity analysis can be used to measure the influence of each factor on employees' efficiency. The authors hope that the results of the DEA model presented in this paper will stimulate further research in the use of DEA in employee evaluation.

The findings of this research study will be important on both the theoretical and the practical level. It was almost possible empirically to substantiate the research model developed for this study. The model could be used as a mathematical model of HRM that will contribute practically to knowledge in the field of HRM.

Although the approach used in this research is practical, it is costly and time-consuming owing to the large number of questions it contains. All similar research, being survey-based and conceptual, faces the same difficulty: the quality of the data is questionable. There were 55 subjects in this sample; but the number of subjects should be increased in order to improve the reliability of the research. The study was also limited to one company, and may not be applicable to other companies. This study was limited to an analysis of HRM factors and the impact on employees' efficiency in an Iranian pipe company. Further investigations in other kinds of industries may offer additional insight into the findings of this study. Another important limitation is that this analysis was cross-sectional in nature. Additional longitudinal research is suggested in order to assess the impact of the factors over time.

\section{REFERENCES}

[1] Cook, F.L. 2001. Human resource strategy to improve organizational performance: A route for firms in Britain? International Journal of Management Reviews, 3(4), 321-339.

[2] Bacon, D.R. 2003. A comparison of approaches to importance-performance analysis. International Journal of Market Research. 45(1), 55-71.

[3] Matzler, K., Sauerwein E. \& Heischmidt, K.A. 2003. Importance-performance analysis revisited: the role of the factor structure of customer satisfaction, The Service Industries Journal, 23(2), 112-129.

[4] Eskildsen, J.K. \& Kristensen. K. 2006. Enhancing importance-performance analysis. International Journal of Productivity and Performance Management, 55(1), 40-60.

[5] Wood, S. \& Wall. T. 2002. Human resource management and business performance, in Warr, P. (ed.), Psychology at work, Penguin, London, 351-374.

[6] Zacharatos, A., Hershcovis, M.S., Turner, N. \& Barling, J. 2007. Human resource management in the North American automotive industry: A meta-analytic review. Personnel Review, 36(2), 231-254.

[7] Cooper, W.W., Deng, H., Huang, Zh. \& Susan, X.L. 2004. Chance constrained programming approaches to congestion in stochastic data envelopment analysis, European Journal of Operational Research, 155(2), 487-501.

[8] Allen, N.J. \& Meyer, J.P. 1996. Affective, continuance, and normative commitment to the organization: An examination of construct validity, Journal of Vocational Behavior, 49, 252-76.

[9] Biggs, D. \& Swailes, S. 2006. Relations, commitment and satisfaction in agency workers and permanent workers, Employee Relations, 28(2), 130-143.

[10] Swailes, S. 2002. Organizational commitment: A critique of the construct and measures, International Journal of Management Reviews, 4(2), pp. 155-78. 
[11] Bergmann, T.J., Lester, S.W., De Meuse, K.P. \& Grahn, J.L. 2000. Integrating the three domains of employee commitment: An exploratory study. Journal of Applied Business Research, 16(4), 15-26.

[12] Boles, F., Madupalli, R., Rutherford, B. \& Wood, F.A. 2007. The relationship of facets of salesperson job satisfaction with affective organizational commitment, Journal of Business \& Industrial Marketing, 22(5), 311-321.

[13] Spector, P. 1997. Job satisfaction: Application, assessment, cause and consequences, Sage Publications, London.

[14] Crossman, A. \& Abou-Zaki, B. 2003. Job satisfaction and employee performance of Lebanese banking staff, Journal of Managerial Psychology, 18(4), 368-376.

[15] Bhuian, S.N. \& Menguc, B. 2002. An extension and evaluation of job characteristics, organizational commitment and job satisfaction in an expatriate, guest worker, sales setting, Journal of Personal Selling \& Sales Management, 22(1), 1-11.

[16] Brown, S.P. \& Peterson, R.A. 1994. The effect of effort on sales performance and job satisfaction, Journal of Marketing, 58(2), 70-80.

[17] Netemeyer, R.G., Johnston, M.W. \& Burton, S. 1990. Analysis of role conflict and role ambiguity in a structural equations framework, Journal of Applied Psychology, 75(2), 148-57.

[18] Koh, H.C. \& Boo, E.H.Y. 2004. Organisational ethics and employee satisfaction and commitment, Management Decision, 42(5), 677-693.

[19] Kim, D. 2006. Employee motivation: Just ask your employees, Seoul Journal of Business, 12(1), 19-35.

[20] Farrell, M.J. 1957. The measurement of productive efficiency, Journal of the Royal Statistical Society, Series A, General. 120(3), 253-281.

[21] Charnes, A., Cooper, W.W. \& Rhodes, E.L. 1978. Measuring the efficiency of decision making units, European Journal of Operational Research, 2(6), 429-444.

[22] Hackman, J. \& Oldham, G. 1980. Work redesign, Addison-Wesley, MA.

[23] Hackman, J.R. \& Oldham, G.R. 1976. Motivation through the design of work: Test of a theory, Organizational Behavior and Human Performance, 16(2), 250-279.

[24] Spector, P.E. 1985. Measurement of human service staff 198 OCCUPATIONAL MEDICINE satisfaction: Development of the Job Satisfaction Survey, Am J Community Psychol, 13, 693-713.

[25] Mowday, R.T., Steers, R.M. \& Porter, L.W. 1979. The measurement of organizational commitment, Journal of Applied Psychology, 74(2), 224-250.

[26] Price, J.W. \& Mueller, C.W. 1986. Absenteeism and turnover of hospital employees, JAI Press, Greenwich, Conn.

[27] Andersen, P. \& Petersen, N.C. 1993. A procedure for ranking efficient units in data envelopment analysis, Management Science, 39(10), 1261-1264.

[28] Arthur, J.B. 1992. The link between business strategy and industrial relations systems in American steel minimills, Industrial and Labor Relations Review, 45(3), 488-506.

[29] Delaney, J.T. \& Huselid, M.A. 1996. The impact of human resource management practices on perceptions of organizational performance, Academy of Management Journal, 39(4), 947-969.

[30] Huselid, M.A. 1995. The impact of human resource management practices on turnover productivity, and corporate financial performance, Academy of Management Journal, 38(3), 635672.

[31] Huselid, M.A., Jackson, S.E. \& Schuler, R.S. 1997. Technical and strategic human resource management effectiveness as determinants affirm performance, Academy of Management Journal, 40(1), 171-188. 